\title{
Analysis of Causality between Monetary Policy and Economic Growth in Pre- and Post- Deregulated Nigeria Economy. (1970-2009)
}

\author{
${ }^{1}$ Olusanya, Samuel Olumuyiwa, ${ }^{2}$ Akinade Olushina Matthew \\ 1. Lecturer Lagos State University External system, Nigeria. ECONOMICS DEPARTMENT \\ 2. Lecturer Lagos State University External system ECONOMICS DEPARTMENT
}

\begin{abstract}
The research study takes a look at analysis of Causality between Monetary Policy and Economic Growth in Pre-and Post- deregulated Nigeria Economy (1970-2009). Granger causality analysis was used in order to test the hypotheses about the presence of causality between Money supply and Economic Growth. The study, using annual data covering the period between 1970-1985, 1986-2009 and 1970-2009, showed causality relationship from economic growth (GDP) to money supply $(M S)$ in the pre-deregulation era, which implies that there is causality relationship from economic growth to money supply (MS). In the post-deregulation era there is no casual relationship between economic growth (GDP) and money supply (MS). However, in the whole period 1970-2009 economic growth (GDP) is the cause of money supply (MS) in the pre-deregulation era, which implies that there is causality relationship from economic growth to money supply (MS). In other words, there is a one-way relationship between Money supply (MS) and economic growth (GDP).
\end{abstract}

Keywords: Money supply, Economic Growth, Granger Causality test, Deregulation Economy, Economic Growth.

\section{Introduction}

The conduct of monetary policy in Nigeria under the colonial government was largely dictated by the prevailing economic condition in Britain. The instrument of monetary policy at that time was exchange rate which was fixed at par between Nigeria pound and British pound. This was very convenient as fixing exchange rate provided a more effective mechanism for the maintenance of balance of payment viability and for the control over inflation in the Nigerian economy.

This fixed parity lasted until 1967 when the British pound was devalued, owing to the war in the later part of this period. The monetary authority did not consider it expedient to devalue the Nigeria pound in sympathy with the British pound. Two major reasons account for this: First, a considerable proportion of the country's resources were being diverted to finance the war. Second, there was apprehension that the devaluation of Nigerian pound would only raise domestic price of imports without any appreciable impact on exports which were largely primary products.

Rather than devalue, the monetary authorities decided to peg the Nigeria currency to US dollar, but imposed severe restrictions on import via strict administration control on foreign exchange.

From 1970, the economy witnessed major structural changes that affected the conduct of monetary policy. These included the international financial crisis of the early 1970s which led to the devaluation of dollar; Nigeria abandoned the dollar peg and kept faith with pound till 1973, when the Nigerian currency was once again pegged to the US dollar.

With these developments, the severe drawbacks in pegging the Nigerian currency to a single currency became obvious. A clear case was that Naira had to undergo a de facto devaluation in sympathy with dollar when economic fundamentals dictated otherwise in 1973 and 1975 respectively.

It was against this backdrop that the need to independently manage the exchange rate of Naira was firmly established.

Another structural change the economy witnessed was that oil dominated the export basket constituting $57.6 \%$ of total export in 1970 and over $96 \%$ in 1980, while non-oil export, mostly agricultural sector declined rapidly from $42.4 \%$ in 1970 to $16.9 \%$ in 1973 . As a result of the increased revenue accruing to the government from oil, the imbalance in the balance of payment and low external reserves became things of the past. Indeed, Nigerians external reserves rose rapidly by over 1000\% in 1975.

The need to finance the post war development also led to a considerable growth in public expenditure, this intensifying inflationary pressure. Under these circumstances, the monetary authorities adopted a new monetary policy framework. This development marked the beginning of monetary targeting in Nigeria which involved the use of market and non-market instruments. Consequently, the major focus of monetary policy was 
predicted on controlling the monetary aggregates, a policy stance which was largely based on the belief that inflation is essentially a monetary phenomenon.

However, there is an opinion that is unanimously agreed upon that Nigerian economy crisis requires more comprehensive policy response that will address the need to stabilize, diversify and structurally adjust the economy through preferable strategy to gear up the non-oil tradable sector.

However, one major problem that attracts the attention of the Nigeria policy makers is that of disengaging the economy more quickly from oil based foundation in the medium term and it is realization of these objectives that the Structural Adjustment Programme (SAP) was implemented in Nigeria. But it is quite unfortunate that some of policy measures introduced under the banner of this economic reform programme are not posting the desired effect in terms of promoting the economy.

One of the basic objectives which monetary policy is designed to tackle is inflation. Often, a major cause of inflation in most developing countries has been excessive growth in money supply. Monetary expansion leads to a rise in price in the domestic economy, with negative implication on interest rate, exchange rate and output growth.

It must be noted that monetary expansion is triggered by large fiscal shock. Hence, considerable attention must be paid to the size of the fiscal deficit and the mode of its financing. However, the objective of the study is to appraise the relationship between Gross Domestic Product (GDP) and interest rate, to also determine the effect of money supply on the Gross Domestic Product (GDP) and to analyze the effect of exchange rate on the Gross Domestic Product (GDP).

\section{Literature Review And Theoretical Framework}

Monetary policy refers to the combination of measures designed to regulate the value and cost of money in an economy, in consonance with expected level of economic activity. An excess supply of money would result in excess demand for goods and services, which would cause rising prices and/or a deterioration of the balance of payment position. On the other hand, an inadequate supply of money could lead to undue stagnation in the economy. Authority must attempt to keep the money supply growing at an appropriate rate to ensure sustainable economic growth and maintain internal and external stability.

Monetary policy is proposed by the CBN through a memorandum usually titled monetary, credit, foreign trade and exchange policy proposals, which is for a particular fiscal year. The memorandum, an input of all the policy departments of the Central Bank of Nigeria is coordinated by the Research Department. The input takes into account the views and suggestions of financial system operators, the business community, and her interested members of the public. It also considers the prevailing economic conditions, prospect and the policy objectives that appear most appropriate to be pursued in the immediate future.

The memorandum is initially considered by the committee of the Governors, the highest management body for the day to day administration of the CBN. It is finally discussed, amended if necessary and approved by the Board of Directors of the bank.

The proposals are subsequently outlined to banks and other financial institutions by the Central Bank of Nigeria in the form of monetary policy circular for compliance. Ojo (1986) posts that economic environment that guided monetary policy before 1986 was characterized by the growing importance of oil sector, the expanding role of public sector. In order to maintain price stability and a healthy balance of payment position, he opines that monetary management depends on the use of direct monetary instruments such as credit ceilings, selective credit controls, prescription of cash reserve requirements and special deposits.

The use of market base instruments was not feasible at that point because of underdeveloped nature of the financial markets and the deliberate restrain on interest rates. Therefore, the most popular instrument of monetary policy was the issuance of credit rationing guidelines, which primarily set the rates of exchange for the components and aggregate of commercial bank loans and advances to the private sector.

In the post SAP era, he pointed out that the Structural Adjustment Program (SAP) was adopted in July 1986 against the crash in the international oil market and the resultant deteriorating economic conditions in the country, designed to achieve fiscal balance and balance of payments viability by altering and restructuring the production and consumption patterns of the economy eliminating price distortion reducing the heavy dependence on crude oil exports and consumer goods imports, enhancing the non-oil export base and achieving sustainable growth among others.

The main strategies of the programme he posited were the deregulation of external trade and payments arrangements, the adoption of market determine exchange rate for the Naira, substantial reduction in complex price and administrative controls and more reliance on market forces as a major determinant of economic activity.

In his analysis, he concurs that the objectives of monetary policy since 1986 have remained as in the earlier period vis-à-vis; the stimulation of output and employment, and the provision of domestic and external stability. The CBN in 1990 introduced a set of prudential guidelines for licensed banks which were 
complementary to both the capital adequacy requirement and the statement of standard accounting practices. The prudential guidelines, among others, spelt out the criteria to be employed by banks for classifying nonperforming loans. The CBN has continued to examine and monitor banks in order to promote stable banking system. Also the bank handles the problem of distressed and liquid banks.

The CBN imposes holding actions and revolves licenses of affected banks as well as encourages mergers and acquisition in an effort to improve the operations of the money market in auction-based market for treasury securities was introduced in 1989, and there treasury instrument were made bearer bills to enhance transferability and promote secondary trading.

\section{Monetary And Fiscal Policy Syntheses}

Monetary policy refers to the actions of the monetary authorities to influence aggregate demand in the economy by regulating the cost, value and availability of credit. The monetary authority can influence both the cost and availability of credit by measures designed to affect the country's supply of money. The common measures adopted include open market operation (OMO), interest rate policy (i.e. cost of credit) variations in reserve requirements and other special deposits and direct controls over lending by banks and other financial institutions.

Fiscal policy refers to set of actions taken by the government to influence aggregate demand in the economy by regulating the public expenditure and the rates of taxation. Thus given the likelihood of "balance budget", the government can run a budget surplus by spending deficit, by spending more than it raises in taxes, the excess spending being financed either by borrowing or printing of more money. Thus the major instruments of fiscal policy are tax rates and government spending. The role of monetary and fiscal policy in attaining macro economic targets forms part of the solutions to the policy optimization problem. The achievement of which in practice requires a delicate balancing of objectives and instruments.

The rule is that an expansionary monetary policy ought to be matched with tight fiscal policy in order to achieve both internal and external balance. The reverse is also true. Assume an open economy having a fixed target rule with two target goals and two instruments. The economy will achieve both internal and external balance by taking appropriate fiscal and monetary policy actions. The policy target is to achieve full employment of real income and equilibrium in the balance of payments. The two instruments of monetary and fiscal policy will be the changes in money supply and variation in government spending.

The linkage between fiscal and monetary policy has a theoretical foundation. Government deficit is positively related to money supply. Simply put, the amount of government spending through borrowing or printing money, the larger will be the stock of money in circulation vice versa. Using the balance sheet method, we can illustrate the link between monetary and fiscal actions exposed by Nnanna (2003).

\section{Monetary Policy Objectives And Instruments In Nigeria}

The treatment of monetary is at the heart of the macro economic policy making in Nigeria for at least two reasons. First, money in its various forms i.e. whether as cash or interest bearing deposits, represents the single most important financial asset held by the non-bank public. Given its relevant in the portfolio of assets of wealth holders, changes in real value of money have important wealth and distributional effects. Secondly, academic and policy makers recognized the fact that the establishment and maintenance of macro economic stability are crucial for creating the appropriate environment for rapid and sustainable economic growth as well as poverty alleviation. In practice, price stabilization in Nigeria and many other developing countries is tantamount to control of domestic money supply, which is the central problem of monetary policy in Nigeria. Monetary policy is so important because its changes are expected to 'validate' or 'accommodate' the undesirable consequences of other macro-economic polices such as fiscal, trade and exchange rate policy.

From experience and wide spread opinions, there is the consensus that the single most important goal of monetary policy is the pursuit of price stability. This is because an increasing number of Central Banks in virtually all parts of the world are being given exclusive objective of controlling inflation and preserving the stability of domestic prices. Even though economic wisdom suggests that the goal of economic policy is to create enabling environment for private sector development that foster sustainable growth, the primary objective of inflation control is also recognized, since inflation is intrinsically and directly associated with macro economic instability; a situation, which is often sustained by persistent influx of excess money or credit.

According to Fisher (1996), "the fundamental task of the Central Bank is to preserve the value of the currency, this does not mean that other policy objectives are to be neglected"... "In effect, the Central Bank could also be assigned risk of promoting growth, but it has to be understood that this is best done by maintaining a low rate of inflation and ensuring the good health of financial system". Fisher, (1995) "it is also important to note that monetary policy should include with it exchange rate policy in a typical analytical framework. This is because the level and volatility of the exchange rate can usually be taken care of through achieving low rate of inflation which monetary policy generates and sustains"(Oyejide; 2002). Still on the compatibility of monetary 
and exchange rate policy, Mundell (1968) and McKinnon (1971) regard exchange rate policy as a facet of monetary policy. Exchange rate is crucial to the monetary policy because the main objective of monetary policy is price stability, and the volatility of exchange rate is generally counter productive to the goals of price stability; known well too, that exchange rate is politically sensitive in both developing and developed economies. It is therefore important that monetary policies are designed to reconcile the twin objectives of price and exchange rate stability.

According to Ogwuma (1994), the objectives of monetary policy are broadly to promote monetary stability and enhance economic development. Both objectives are reinforcing to the extent that monetary stability forms the bases for sustainable growth. The CBN (2001) included the maintenance of a healthy balance of payments position in order to uphold the external value of the national currency. In the word of Sanusi (2001), he expanded the list of Nigeria's monetary policy objectives to include:

- Achievement of domestic price and exchange rate stability;

- Maintenance of healthy balance of payment position;

- Development of a sound financial system; and

- Promotion of rapid and sustainable rate of economic growth and development.

Although Sanusi had cause to conclude that in line with global developments, more emphasis is now placed on price stability, because other objectives of economic policy are easily derived from maintenance of macro economic stability, Sanusi (2001).

\section{Instruments Of Monetary Policy In Nigeria}

Monetary policy instruments are the techniques available to the authorities, such as Central Bank of Nigeria, for influencing the supply, allocation and cost of credit in an economy. These techniques can easily be classified into two: the quantitative and qualitative technique.

Under the quantitative techniques, we have:

(a) Open Market Operation (OMO);

(b) Bank Rate Policy; and

(c) Reserve Ratio

The qualitative instrument is the selective credit control (moral suasion).

\section{The Open Market Operation}

This is the sales and purchase of securities in the open market (money market) by the Central Bank. In practice when prices are rising and thus requires control, the Central Bank sells securities. This will reduce the reserve with commercial banks, thereby reducing their lending capacity to the business community. Private investment and prices will drop. But during recession (or deflationary period), the Central Bank buys the securities and the commercial banks reserves will consequently rise. The commercial banks will lend more leading to rise in investment, output and employment.

In Nigeria, OMO is conducted weekly at the secondary market with the discount houses as principal dealers.

\section{Bank Rate}

This is the minimum lending rate of the Central Bank which is rediscounts as first class bills of exchange and government securities held by the commercial banks. During inflation period the Central Bank raises the bank rate thus making it difficult for the commercial banks to borrow from it. This action will reduce the lending power of commercial banks. The commercial banks will be forced to increase the interest rate at which the business community borrow from them. This will lead to contraction of credits, investment, aggregate demand and prices. Conversely, during recession, the Central Bank will lower bank rate which will encourage borrowing by the commercial banks, they will in turn lower interest rate for the borrowing public. This will boost private investment, output, employment and aggregate demand.

\section{Reserve Ratio}

This requires the commercial banks law to keep a certain percentage of its total deposits in form of a reserve fund in its vault and also a certain percentage with the Central Bank (reserve requirement).During inflationary period, the reserve ratio will be raise and commercial banks will be required to keep more with the Central Bank. Their reserves are reduced and they lend less. The volume of investment, output and employment will be reduced. But during recession (deflation), the Central Bank lowers reserve ratio. This raises lending capacity of commercial banks and improves investment, output and employment. In Nigeria, the reserve requirement is $12 \%$ and $40 \%$ liquidity ratio for commercial banks. 


\section{Selective Credit Control}

This involves special directives to the commercial banks by the Central Bank on sectoral allocation of loans. Often, government advises commercial banks against speculative lending in favour of more productive sectors such as agriculture, industries, transport etc.

As a final note, expansionary monetary policies are taken during the period of recession or deflation. These policy actions help raise the pace of economic activity thereby raising output and employment. Such expansionary policy activities include purchase of securities by the Central Bank in the open market, lowering of bank rate, lowering of commercial banks reserves and encouraging credits of commercial banks to the productive sectors. On the contrary during inflationary period, the monetary authority takes a contractionary or restrictionary monetary policy by sales of securities in the open market, raising bank rate and reserve ratios.

\section{Strategies And Effectiveness Of Monetary Policy Implementation In Nigeria.}

Monetary policy strategy deals with how central bank carries out monetary policy. And what is central to the form of monetary policy strategy is the choice of the different nominal anchor. For example, we have the monetary targeting by using the information on the monetary aggregates to conduct monetary policy. "Monetary targeting occurs in two forms. These are the rigid Friedman-type monetary targeting rule in which the chosen monetary aggregate is kept on a constant growth rate path as the focus of monetary policy. The second is the flexible variety, which may involve a set of monetary aggregates, each of which is allowed to grow at different rates" (Oyejide; 2002).

Looking at exchange rate targeting for example, we have the hard peg and soft peg. Hard peg is institutionalized whereas soft peg is not. Under the hard peg exchange rate targeting, rigid commitment may be derived from a currency board type of institutional arrangement, which ties one currency to another. At these circumstances, the monetary authorities such as Central Bank give up the independent power of monetary policy. Such approach is expedient for countries having weak political and monetary institutions that can achieve macro economic stability.

A monetary policy target such as inflation (price level) target is very popular one aimed at achieving price stability as the primary goal of monetary policy. However, inflation target requires strong Central Bank's instrument independence, rich data environment, prudent fiscal policy behaviour and robust financial institutions. It is important to note that economic policy goals such as growth in output, employment, real exchange rate. BOP and inflation rate are difficult for Central Bank to control directly. This is mostly, as a result of the problems of transmission mechanism. For any policy action to achieve desirable results there will always be need for an accurate data environment, identifying key intermediate variables and ability to determine time lag between when policy is taken and when the effects on the real economy will begin to materialize.

Intermediate target variables include the money supply aggregate (M1 and M2), the short term interest rate and the exchange rate. In Nigeria today, there are several other features of monetary policy strategy used in conjunction with these intermediate target variables. "We now have public announcement of medium term numerical targets, increased transparency of the monetary policy process through increased communication with the public and financial markets" (Oyejide; 2002). Sanusi (2001) claimed that "In Nigeria, exchange rate targeting regime held sway during 1959-1973 when the exchange rate was regarded as the nominal anchor for monetary policy, while the period 1974-2001 was assigned to monetary targeting regime with the focus of controlling monetary aggregates so as to achieve stability of macroeconomic variables and monetary policy goals". This observation was contrast to the CBN reports, which stated that the strategy of monetary policy in Nigeria has been targeted on money supply growth. In fact, M1 constituted the primary focus before 1986, and M2 replaced M1 since 1986. Ojo (1999) held an independent opinion to this, "Nigeria experienced an era of regulation (up to 1986) which featured direct controls on quantitative ceilings on bank credit, sectoral credit allocation and interest rate regulation". The aim was to restrain the growth in money supply, using the cash reserve requirement changes as supplementary measures when necessary. The second era (since 1986) featured market based approach to monetary policy strategy. Bank credits are financed through changes in banks reserve, which are engineered through open market operation and activities of discount window.

Again in CBN Bullion publication, April/July 2000, Ojo observed that additional medium to long-term policy measures are now been put in place to ensure proper liquidity management in improving financial environment in Nigeria. Such measures include the introduction of national saving certificate of 3-5 year maturity, Federal Government Development loan stock, vibrant inter-bank market, NDIC impact, universal banking etc. the minimum paid up capital of $\$ 500$ million introduce in 1990 is now $\$ 1$ billion for old and new banks respectively, effective from January 1, 2000. We also have Agricultural Credit Guarantee Scheme (ACGS) with capital base of at least $\$ 1$ billion and for short term and medium term agricultural loans, and the small scale industry loan scheme (10 percent banks profits set aside). However, Nigeria has not had a long 
history of market based monetary strategy or a true reflection of CBN autonomy, which of course will affect the execution of monetary policy in the economy.

\section{Overview Of Monetary Policy In Deregulated Nigeria Economy.}

In Nigeria, we had direct monetary control techniques in the years 1960s, 1970 and 1980s until June 1986. The main monetary policy objectives were the maintenance of relative price stability and exchange rate stability to ensure healthy balance of payments position.

However, the major instruments used were administered interest rates, special deposits, administered exchange rates, and prescribed cash reserve requirement and selective credit controls. The most popular was the issuance of credit rationing guidelines i.e. rates of change of the components and aggregate commercial banks loans and advances to the private sectors. Given the fact that the economy and indeed the financial market were narrowly underdeveloped, it was not feasible to adopt the market-base tools of monetary policy and techniques. Interest rate was controlled to remain at low level in order to promote investment and growth, and to reduce commercial banks reserves and their credit creation capacity, the special deposit requirements were occasionally imposed. The minimum cash ratios was applied only on the bases of banks deposit liabilities and sectoral allocation of bank credit favoured productive sector such as agriculture, industry, construction etc. so as to ensure speedy economic growth and stem inflationary pressures.

More over, by middle 1980s following the introduction of SAP, more indirect monetary techniques were adopted. This was because of the emergence of market-oriented financial system, which requires effective mobilization of financial saving effective resources allocation. Apart from achieving the primary goals of price and exchange rate stability, there was the urgent need for economic growth and employment in the new policy regime. The monetary policy activities since the introduction of SAP can be summarized as in the work of Anyanwu (1997):

- Deregulation of interest rate in August 1987, though with an upper limit of $21 \%$ on lending rate and floor level of $13.5 \%$ for saving, prescribed the difference between deposit and lending to 4 percent spread points;

- To reduce the adverse effect of high interest rate on productivity, the strict interest rate deregulation had been reverse since Nov. 1993;

- Increase commercial bank cash reserve requirement in 1989, 1990 and 1992;

- Merchant bank liquidity ratio varied from 39\% of demand deposits and call money to $20 \%$ of total deposits, but rose again by 1990 .

- Public sectors accounts were transferred from commercial bank to Central Bank.

- Issuance of stabilization securities particularly in 1990 to mop up excess liquidity.

- 1991 saw the calculation of cash reserve requirement based not only on demand deposit but including time and saving deposit.

- Since September 1992, the CBN released to the financial system in Nigeria serious prudential guidelines, growth oriented sectoral credit allocation and sound financial management. To this extent there was increased minimum paid-up capital requirement, capital adequacy ratio, and minimum cash reserve and liquidity ratio requirement.

- Open market operation was introduced in June 30, 1993 by the CBN. This led to the buying and selling of government securities such as treasury bills, treasury certificates and government development stocks. OMO was used to achieve substantial monetary tightening so as to reduce inflationary pressures and continuous fall in the foreign exchange value of Naira. According to Nnana (2002).

- There was CBN decree 24 of 1991 and Banks and Financial Institutions Decree (BAFID) 25 of 1991. Also, there was CBN amendment decree 37 of 1998 and BAFID 38 of 1998 that grant CBN more discretion and autonomy (from the control of the ministry of finance) in the conduct of monetary policy.

- Cash reserve requirement (CRR) was increased from 6\% in 1995 to 8\% in 1997 and 12.5\% in April 2001.

- Minimum rediscount rate (MMR) which influences other interest rates was reviewed upward from $18.5 \%$ in June 2001 to $20.5 \%$ in September, 2001 so as to contain the rapid monetary expansion arising from the expansionary fiscal policy of the three tiers of government in Nigeria.

Indeed, OMO has been the principal instrument of liquidity management, complemented by reserve requirements (cash reserve requirement and statutory minimum liquidity ratios), discount window operations and very recently the issuance of $\mathrm{CBN}$ certificates. Interest rate is market determined and influenced by the $\mathrm{CBN}$ in line with the desired macro economic objectives including price and exchange rate stability, through adjustments of its Minimum Rediscount Rate (MRR). The 2002/2003 monetary policy circular of CBN adopted new medium term monetary framework to take care of the lagged effect of monetary policy on the ultimate objectives. This is to avoid time inconsistency in implementation and over reaction of the economy due to temporary shocks. 


\section{Theoretical Framework}

This presents the theoretical literature on the impact of monetary policy in the context of Monetarists and Keynesians views

\section{The Monetarists: Monetary Theory}

The monetarists are the modern non-Keynesian economists with classical roots who assigned causal roles to money, treating it as being exogenous. They assert that there is a direct relationship between money supply and level of price which is proportional in the long run.

They argue that long run is the time period when all expectations are realized while the short run is marked as unanticipated changes. Thus in the short run, money supply affects the output within five to ten years while in the long run, it changes mainly prices within a time period of more than ten years (Anyanwu;1993).

The classical view of how money affects the economy may be considered in terms of the famous "equation of exchange" formulated by Irving Fisher of university of Vale. The equation is normally stated as:

$\mathrm{MV}=\mathrm{PT}$

Where, $\mathrm{M}=$ the nominal money supply (the value of currency in circulation); V=velocity of circulation of money; $\mathrm{P}=$ the general price level and $\mathrm{T}=$ volume of transaction per unit of time. From the above, equation of exchange is a truism. That is assuming MV is equal to the value of sales per period and since no one makes a sale until some other person spends, then it implies that MV is equal to PT.

Although, the equation has been interpreted in several ways; it is often regarded as an identity just as Keynes (1936), once stated that "the quantity theory is a truism which holds in all circumstances without a significant",

The formula is the basis of the quantity theory of price, when the assumption that velocity (V) and number of transaction (Y) are fixed for a significant period of time. It is equally assumed that the price level would adjust automatically towards its full employment of output following any changes in the pattern of demand of resources availability. Thus the equation of exchange would be re-written as:

$$
\mathrm{P}=\mathrm{MV} / \mathrm{T}
$$

Since V and T are constant, then the conclusion is that price level is directly proportional to the stock of money in economy. The rational for this result is that people are assumed to hold money only as medium of exchange. Therefore, money is neutral in the classical system since it determines only the absolute prices and has no effect on the relative prices. The quantity theory of price holds that price moves proportionally with the supply of money.

\section{Monetarists' Transmission Mechanism}

The monetarists' transmission mechanism recognizes that money is not just a close substitute for a small financial asset but also as a three-way asset. This allows money to have a direct effect on consumption as well as giving it the possibility of operating through the Keynesian investment-consumption mechanism; thus given an equilibrium position, an increase in money supply raises the actual proportion of money relative to desired proportion. People react by getting rid of excess balances. The transaction in securities affects relative prices and interest rates. Transaction need of different sectors rise and increase in the purchase of goods and services ensue.

The decline in interest rate encourages investment spending. The interest rate serves to facilitate real and financial asset adjustments, though the impact of changes in money on any specified interest rate is too brief to be captured statistically, or identify as a strategic variable in the transmission mechanism (Anyanwu1993). Therefore the monetarists view the money supply as the strategic variables affecting income directly. Symbolically, the monetarist' monetary transmission mechanism is presented as:

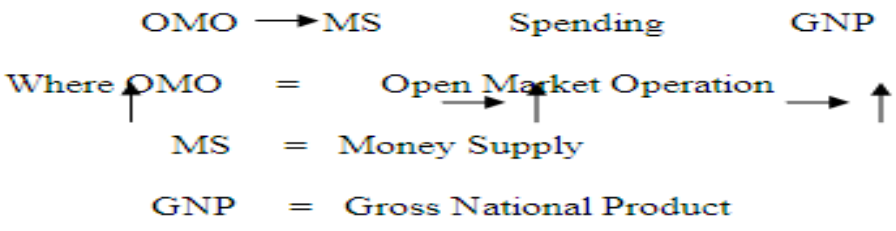

\section{The Keynesian Monetary Theory}

The Keynesian school of thought is referred to as the twentieth century economist who adopted and extended Keynes belief in the possibility of persistent unemployment equilibrium. This school of thought was the dominant force in macroeconomic analysis from the late 1930s until the mid of 1970s. It provides not only 
the most widely used framework for theoretical discussion but also formed the basis of macroeconomic policy in most western countries.

The Keynesian argument is based on the fact that government (including monetary authorities) would interfere in the operation of the economy and should specifically use its power of macroeconomic management to ameliorate the socially and economically undesirable problems of unemployment. It was their belief that the natural market force within the economy will never produce automatic solution to macroeconomic problems. The great depression of the 1930 did so much to destroy the notion of self-regulating economy. This inspired John Maynard Keynes to publish a book titled "The General Theory of Employment, Interest and Money" in 1936 in which he debunked the notion of self-regulating economy.

\section{Keynesian Transmission Mechanism}

In the Keynesian analysis, the primary link between money supply and the economy is the interest rate. But there are two other secondary links: these are ability of interest rate to influence national income. Here, the Keynesians assumption is that the economy is at less than full employment. According to the Keynesians, the transmission mechanism works through financial system to the real sector (an indirect relationship).the Keynesian transmission mechanism is characterized by highly detailed sector -by-sector building of aggregates demand and detailed specification of portfolio adjustment process that attaches a central role to interest rates as an indirect link between monetary policy and final demand (Crews; 1976).

If for instance, the economy is initially at equilibrium and there is an open purchase of government securities by the Central Bank, the Open Market Operation (OMO) will decrease the commercial bank reserves (CR) and raise the bank reserve earning asset ratio (R). The banks then operate to their desired level by extending new loans or by expanding bank credit in other ways. Such new loans create new demand deposits thus increasing the money supply (MS).

Given the public liquidity preference, a rising money supply causes the general price level of interest rates to decline. A falling interest rate will in turn stimulate investment given businessmen's expected profit expressed as the Marginal Efficiency of Investment (MEI).

That is a declining rate or falling capital cost induce expanded investment expenditures causing successive rounds of new final demand spending and causing GNP to rise by multiple of the initial change in investment (Silber; 1969).

The Keynesian transmission mechanism can be summarized as:

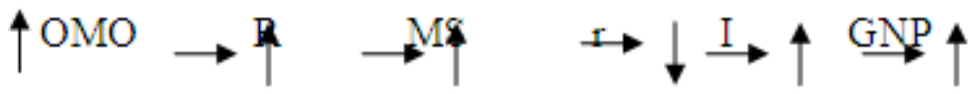

Where OMO = Open market operation; $\mathrm{R}=$ Banks Reserve Requirement; $\mathrm{r}=$ Interest Rate; MS = Money Supply; I = Investment and GNP = Gross National Product.

\section{Synthesis Of The Monetarists And Keynesian Monetary Theory}

Over the years, the issue of how and to what extent changes in money supply affect an economic system had been debated among the various schools of thought. The Monetarists believe that money supply only matters in stimulating aggregate demand price and output while the Keynesians contend that money does not matter. Both schools believe that money is a form of asset to be held for its own-sake and not just at temporary abode of purchasing power as believed in the old quantity theory. However, in terms of substitution, Keynesians believe that only bond is a substitute for money while the Monetarists believe that all kinds of assets both financial and real are substitutes for money (Anyanwu: 1993).

The Monetarists and Keynesians do believe that money can influence the GNP. However they perceived that transmission mechanism in different ways. While the Monetarists opined that money has direct effect on GNP, the Keynesians posited that the effect of money supply on the GNP is indirect through interest rate.

\section{Methodology}

While conducting an econometric study, the direction of the causal relationship among variables is determined according to the information obtained from the theory. Classical regression analysis is based on the assumption that the method used is correct and the direction of the causality is determined in the model. Therefore; in this study Granger causality test will be used in order to test the hypotheses regarding the presence and the direction of causality between monetary supply (MS) and economic growth (GDP).

The Granger causality test is a statistical hypothesis test for determining whether one time series is useful in forecasting another. Ordinarily, regressions reflect "mere" correlations, but Clive Granger, who won a Nobel Prize in Economics, argued that there is an interpretation of a set of tests as revealing something about causality. A time series X is said to Granger-cause Y if it can be shown, usually through a series of t-tests and F- 
tests on lagged values of $\mathrm{X}$ (and with lagged values of $\mathrm{Y}$ also included), that those $\mathrm{X}$ values provide statistically significant information about future values of $\mathrm{Y}$.

If a time series is stationary, the test is performed using the level values of two (or more) variables. If the variables are non stationary, then the test is done using first (or higher) differences. The number of lags to be included is usually chosen using information criteria, such as the Akaike information criterion or the Schwarz information criterion. Any particular lagged value of one of the variables is retained in the regression if (1) it is significant according to a t-test, and it and the other lagged values of the variable jointly add explanatory power to the model according to an F-test. Then the null hypothesis of no Granger causality is retained if and only if no lagged values of an explanatory variable have been retained in the regression. However, in practice it may be found that neither variable Granger-causes the other, or that each of the two variables Granger-causes the other. As its name implies, Granger causality is not necessarily true causality. If both $\mathrm{X}$ and $\mathrm{Y}$ are driven by a common third process with different lags, one might still accept the alternative hypothesis of Granger causality. Yet, manipulation of one of the variables would not change the other. Indeed, the Granger test is designed to handle pairs of variables, and may produce misleading results when the true relationship involves three or more variables. A similar test involving more variables can be applied with vector autoregression.

Let $\mathrm{y}$ and $\mathrm{x}$ be stationary time series. To test the null hypothesis that $\mathrm{x}$ does not Granger-cause $\mathrm{y}$, one first finds the proper lagged values of $\mathrm{y}$ to include in a univariate autoregression of $\mathrm{y}$ :

$$
\begin{gathered}
y_{t}=a_{0}+a_{1} y_{t-1}+a_{2} y_{t-2}+\cdots+a_{m} y_{t-m}+\text { residual }_{t:} \\
\text { Next, the autoregression is augmented by including lagged values of x: } \\
y_{t}=a_{0}+a_{1} y_{t-1}+a_{2} y_{t-2}+\cdots a_{m} y_{t-m}+b_{p} x_{t-p}+\cdots+b_{q} x_{t-q}+\text { residual }_{t} .
\end{gathered}
$$

One retains in this regression all lagged values of $\mathrm{x}$ that are individually significant according to their $\mathrm{t}$ statistics, provided that collectively they add explanatory power to the regression according to an F-test (whose null hypothesis is no explanatory power jointly added by the x's). In the notation of the above augmented regression, $\mathrm{p}$ is the shortest, and $\mathrm{q}$ is the longest, lag length for which the lagged value of $\mathrm{x}$ is significant. However, the null hypothesis that $\mathrm{x}$ does not Granger-cause $\mathrm{y}$ is accepted if and only if no lagged values of $\mathrm{x}$ are retained in the regression.

\section{Analysis}

In this study, Granger causality test was applied in order to determine the presence of the relationship between two variables and its direction in Nigerian economy between 1970-1985, 1986-2009 and 1970-2009 fiscal years. When the results of the test displayed in the table below are examined, it can be seen that the series belonging to money supply (MS) and economics growth (GDP) is not stationary in level value and it becomes stationary only when first differences are taken.

\section{STATIONARITY TEST}

\begin{tabular}{|c|c|c|c|}
\hline Period & Variable & Ho; I(0) & Ho; I(1) \\
\hline $1970-1985$ & GDP & -2.2513 & -3.3124 \\
& MS & -2.3452 & -5.3211 \\
\hline $1986-2009$ & GDP & -1.5432 & -3.4334 \\
& MS & -11406 & -3.5412 \\
\hline $1970-2009$ & GDP & -1.1765 & -3.7654 \\
& MS & -1.7523 & -4.0926 \\
\hline
\end{tabular}

\section{Critical value at $5 \%=2.93$}

According to the equations above, if the addition of the information about the variable $\mathrm{X}$ to the According to these equations, if the addition of the information about the variable $\mathrm{X}$ to the model contributes to the estimate of the variable Y, the variable X is the cause of the variable Y. Tarl, (2005). When H0 hypothesis is accepted, $\mathrm{X}$ is not the cause of $\mathrm{Y}$. If $\mathrm{H} 1$ hypothesis is accepted $\mathrm{X}$ is the cause of $\mathrm{Y}$. If both hypotheses are rejected, this means there is a two-way causality between $X$ and Y. If "F" value calculated during the testing of the hypothesis is lower than "F" table value, H0 hypothesis is accepted as "there is no causality from X to Y. If "F" value is higher than the table value, H0 hypothesis is rejected and it is said that there is causality from X to $\mathrm{Y}$. All these calculations are applied in the same way in order to test whether there is causality from Y to X. The results of Granger test done for 2 Time lags between the two variables for which unit roots test is carried out are displayed in the table below. 
Pairwise Granger Causality Tests

Sample: 1970 - 1985

Lags: 2

\begin{tabular}{|l|l|c|c|}
\hline Null Hypothesis: & Obs & F - Statistics & Probability \\
\hline GDP does not Granger Cause MS & 15 & $6.54240 *$ & 0.03218 \\
MS does not Granger Cause GDP & & 1.29871 & 0.34123 \\
\hline
\end{tabular}

Pairwise Granger Causality Tests

Sample: 1986 - 2009

Lags: 2

\begin{tabular}{|l|l|c|c|}
\hline Null Hypothesis: & Obs & F - Statistics & Probability \\
\hline GDP does not Granger Cause MS & 23 & 2.43567 & $\mathbf{0 . 1 2 3 3 5}$ \\
MS does not Granger Cause GDP & & 1.11267 & $\mathbf{0 . 4 5 5 2 4}$ \\
\hline
\end{tabular}

Pairwise Granger Causality Tests

Sample: 1970 - 2009

Lags: 2

\begin{tabular}{|l|l|c|c|}
\hline Null Hypothesis: & Obs & F - Statistics & Probability \\
\hline GDP does not Granger Cause MS & 39 & $3.9987 * * *$ & $\mathbf{0 . 0 4 2 3 1}$ \\
MS does not Granger Cause GDP & & 2.3428 & $\mathbf{0 . 1 4 2 3 5}$ \\
\hline
\end{tabular}

$* 5 \%$ Level of significance $=\mathrm{v} 1=2, \mathrm{v} 2=13=3.81$.

$* * 5 \%$ Level of significance $=v 1=2, \mathrm{v} 2=19=3.52$.

$* * * 5 \%$ Level of significance $=\mathrm{v} 1=2, \mathrm{v} 2=35=3.23$.

According to Granger causality test done by using annual data between 1970-1985, 1986-2009 and 1970 and 2009 in Nigeria, economic growth (GDP) is the cause of Money supply (MS) in the pre-deregulation era, which implies that there is causality relationship from economic growth (GDP) to Money supply (MS). In the post deregulation era there is no casual relationship between GDP and MS. However, in the whole period 1970-2009 economic growth (GDP) is the cause of Money supply (MS) in the pre-deregulation era, which implies that there is causality relationship from economic growth to Money supply (MS). In other words, there is a one-way relationship between MS and GDP and the direction of this relationship is from GDP to MS.

\section{RECOMMENDATION}

\section{Recommendation And Conclusion}

Having investigated empirically, the causality between monetary policy on the pre and post deregulated Nigerian economy, it will be very necessary to offer the following recommendations:-

- Monetary policy implementation should be carried out in conjunction with other policies such as fiscal policy, debt management policy and income policy or wage price control measure

- Government should reduce the size of its fiscal deficit because fiscal deficit results in excess liquidity in the banking system and this hampers the impact of monetary policy aimed at reducing excessive money supply.

- The CBN should ensure that growth in money supply should commensurate with the economy's productive capacity.

- Government needs to extensively use its monetary and fiscal policy to influence the level of exchange rate in the economy to strengthen the domestic currency.

- The CBN being the apex bank should ensure that all banks operate within their stipulated rules and regulations especially in credit allocation.

- The CBN should carry out orientation and inculcate the habit of banking in the informal sector through rural banking to mop up excess liquidity in the informal sector.

If the above measures are taken seriously by the government, it is hoped that the monetary policy will continue to impact positively on the growth of the Nigerian economy.

\section{Conclusion}

This study examines the direction of the relationship between economic growth rate and Money supply by using Granger causality test. According to the results of the study, there is no reciprocal causality relationship between economic growth and Money supply in Nigeria. The direction of causality relationship is only from 
GDP to MS and there is no causality relationship from MS to GDP. In other words, GDP in Nigeria is one of the factors affecting the flow of MS. The above findings have important policy implications. Understanding the direction of causality between the two variables is crucial for formulating policies in Nigeria which the CBN has been in the fore front of coordinating and maintaining the money supply and the country's Gross domestic product every quarterly period in a year.

Consequently, this casts some doubts on the validity of policy guidelines which emphasize the importance of MS for growth and stability in developing countries under the assumption that 'MS causes growth'. Increased attention needs also to be given to the overall role of growth (and the quality of growth) as a crucial determinant of MS. As we earlier stated that all economy strives towards tackling inflation, that is attaining economy stabilization but it is the application and the implementation of the appropriate macroeconomic policy to achieve this. That has been the problem. Conclusively, it is based on these aforementioned facts that it is opined that monetary policy has been effective in impacting on the Nigerian economy during the pre and post deregulated economy.

\section{References}

[1] Ademola D (2002), Econometrics Analysis of Monetary Policy and Nigeria Economy, Journal of University of Ibadan, Nigeria

[2] Akatu P.A. (1993), The Challenges of Monetary Policy since 1986, CBN Economic and Financial Review, vol. 31 no 4

[3] Anyanwu J.C. (1993), Monetary Economics: Theory, Policy and Institutions, Hybrid Publisher, Onitsha- Nigeria

[4] Anyanwu (1997), Monetary Policy and SAP in Nigeria, Journal of African Journals, Vol. 16, Pg. 42-54, AURC Publication, Kenya

[5] Anyanwu (1997), Empirical Study of Monetary Policy, A Journal of Africa Economics Consortium, Vol. 8, pg. 11- 24, AEC Publication, Kenya

[6] Anyanwu (1997), Monetarists View Analysis on Monetary Policy, a textbook, 4th edition, pg 13-27, Macmillan Press Limited, Lagos, Nigeria

[7] Anyanwu (1997), Keynesians and Monetarists Views of Monetary Policy, a textbook, 2nd edition, pg. 66-74, BLL Publication Limited, Lagos, Nigeria

[8] Bannock G. (1972), The Penguim Dictionary of Economics, Penguim, Middle Sex, England.

[9] Crews J.M. (1976), Econometric Models: The Monetarists and Non Monetarists views compared in Havrilesky T.M and policy. AMH Publishing Corporation, Artington Heights, Illinois

[10] Fisher (1995), Monetary Policy and Exchange Policy in Sweden, a journal of Sweden School of Economics, vol. 3, pg 36-47, Sweden School Publication Limited, Sweden

[11] Fisher (1996), Trends of Inflationary Policy in Developing Economy, a presentation on Sweden Economy Conference Schcolm, Sweden.

[12] Fuhrer (1997), Monetary Policy Stabilization, a textbook 2nd edition, pg 134-143, McGraw-Hill Publication Limited, New York, USA

[13] Higgins B. (1978), Velocity: Money Second Dimension, FRB Karbas city, Economic Review, June, page 79 to 80

[14] Ibi Ajayi (1994), Transmission Mechanism of Monetary Policy in Developing Country. A journal of Social Sciences, University of Lagos, vol. 4, pg. 33-67, University of Ibadan Press, Lagos, Nigeria

[15] Jhingan M.L. Tenth Editions, Macroeconomic Theory, 1997 Vrinda Publications Limited, Mayar Vihar, Delhi

[16] Mundell (1968) and McKinnon (1971), Exchange Rate Policy Regime, a Journal of University of Belgium, vol. 68, pg. 134 - 149, University of Belgium Press, Belgium

[17] Nnanna (2002), Inflation Pressures and Continuous Fall in Foreign Exchange in Nigeria, a publication of Central Bank of Nigeria, vol. 4, pg 34 - 49, CBN Press Limited, Nigeria

[18] Nnanna (2003), Link Between Monetary and Fiscal Policy in Nigeria, a publication of University of Abuja, Economics Department, vol. 6 pg $113-134$, University of Abuja Press, Nigeria

[19] Obadan M. (2000), Informal Sector Activities in Nigeria, a textbook, $2^{\text {nd }}$ edition, pg. 31- 45, Macmillan Publication, Limited, Lagos, Nigeria

[20] Ogun (2005), Monetary and Fiscal Policy in Nigeria Economy, a Journal of Economics Student Association, University of Ibadan, vol. 1 pg 77- 93, Macmillan Publication Lagos, Nigeria

[21] Ogwuma P. (1998), Money Supply Inflation and the Nigeria Economy, CBN economic and financial review, volume 34 no 6

[22] Ojo (1986), Economics Environment and Monetary Policy, a textbook, $3^{\text {rd }}$ edition pg. 67-79, BBL Publication Enugu, Nigeria

[23] Oyejide (2002), Exchange Rate Volatility in Nigeria, a Journal of University of Ibadan, Faculty of Social Sciences, vol. 18, pg 6794, University Press Ibadan.

[24] Oyejide (2002), Flexibility of Monetary Aggregate in Nigeria, a journal of University of Ibadan, vol.9, pg. 134-152, University Press Ibadan, Nigeria

[25] Oyejide (2002), Monetary Policy and Financial Market in Nigeria, a journal of Faculty of Social Sciences, University of Ibadan, vol. 5 pg 12- 31, University Press Ibadan, Nigeria

[26] Sanusi (2001), Monetary Policy Expansion, a Central Bank of Nigeria publication, vol. 171 pg 64- 79, CBN publication limited 